\title{
Processing Methodology and Dialectological Aspects of the Dictionary of Moravian and Silesian Anoikonyms (Minor Place Names)
}

\author{
LIBUŠE ČIŽMÁROVÁ \\ Department of Dialectology, Institute of the Czech Language of the AS CR, v. v. i. \\ Veveři 97, CS-60200 Brno, cizmarova@iach.cz
}

\begin{abstract}
SCN III/1 [2010], 183-195
Članek predstavlja postopek, ki so ga uporabili jezikoslovci iz Brna, ki pripravljajo Slovar moravskih in šlezijskih anojkonimov (Dictionary of Moravian and Silesian Anoikonyms), in sicer pripravo skupnih vnosov, ki jih uvajajo abstraktne iztočnice. Rezultat bo multifunkcionalni interaktivni digitalni slovar. Gradivo je večinoma posneto v narečju, zato mora biti avtor izkušen dialektolog. Računalniški program omogoča izdelavo kart, ki omogočajo primerjavo z dialektološkimi kartami v Češkem lingvističnem atlasu (Czech Linguistic Atlas).

This paper presents the routines used by Brno linguists working on the Dictionary of Moravian and Silesian Anoikonyms (preparing collective entries introduced by abstract headwords). The output will be primarily a multifunctional interactive digital dictionary. Since most of the material has been recorded in dialect form, the authors must be experienced in dialectology. The computer program offers the possibility to generate maps enabling comparison with dialectological maps of the Czech Linguistic Atlas.
\end{abstract}

Ključne besede: anojkonimi (imena manjših krajev), slovar, interaktivni digitalni slovar, leksikografija, onomastika, dialektologija

Key words: anoikonyms (minor place names), dictionary, interactive digital dictionary, lexicography, onomastics, dialectology

This contribution expands the discussion of The Dictionary of Moravian and Silesian Anoikonyms, conceived in the shape of an alphabetical inventory not of individual minor place names but of collective entries introduced by abstract headwords. The paper is focused on the methodology, on the routines used by Brno linguists working on the Dictionary, and on presenting dialectological aspects of the work. 
The decision was made to produce not only a traditional "paper" dictionary which could only be used in a very restricted way in comparison to a digital format; primarily though, a multifunctional interactive digital dictionary should appear that would enable searching for and grouping the data stored in the database according to various criteria and demands, as well as providing material for further work with them. The decision was therefore taken that the material stored on traditional paper filing cards in Brno would be processed digitally. Concurrently the basis for a traditional, paper version of the Dictionary is occurring which is, however, seen as only one of the future outputs of the digital database of minor place names. The digital dictionary should be published on a portable medium (CD, DVD), possibly also on-line on an interactive web page. Linguists as well as interested persons from the public will then be able to search for various details of information stored in the system. ${ }^{1}$

First of all it is necessary to digitize all the collected material, in contrast to the traditional version of a dictionary that could be conceived and published in sections in alphabetical order ${ }^{2}$.

Both versions of the Dictionary, the traditional as well as the digital, have text parts. This part will be the main component of the traditional version of the Dictionary. By contrast, in the digital version it will serve only as the basis for searching for further information. The text part of the Dictionary is presented as an alphabetical inventory of collective entries introduced by abstract headwords, where an entry is given for each word that occurs in the corpus of the gathered anoikonyms.

Most entries are the so-called common or basic entries containing a one-word headword, the enumeration of respective anoikonyms, and the explanatory part. Besides these entries, the dictionary contains multiple entries, cross-reference entries and summary entries. Multiple entries are variants of common entries: two or more words (differing in the word stem or suffix, in a changing vowel or consonant, or possibly in grammatical gender) are integrated into one entry

\footnotetext{
${ }^{1}$ The server portion of the system has been programmed in the Ruby language by means of the framework Ruby on Rails. As a depository site for the data, the relational database PostgreSQL has been used. The client portion has been constructed in the languages JavaScript and XUL while using the Mozilla program. The formats based on the markup languages XML and RDF have been used as the language for data exchange between the client and server portions of the system.

2 This is the case of the Prague onomastic working group which has already published five fascicles of the Dictionary of Minor Place Names in Bohemia since 2005: the letter A and a part of B (Olivová-Nezbedová and Malenínská 2000; Matúšová (ed.) 2005; Matúšová (ed.) 2006; Matúšová (ed.) 2007; Matúšová (ed.) 2008; Matúšová (ed.) 2009). The Prague group indeed transformed the anoikonymic material from Bohemia into a digital format. However since they began working on their dictionary ten years earlier than the Brno workgroup did, they did not have such digitization possibilities as contemporary developments in computer science offer. Therefore they only stored their data in a common database which serves their internal needs while working on the traditional dictionary.
} 
under one multi-word headword and are treated together as one. Cross-reference entries do not contain any documentary material or explanation. They only refer to cognate basic entries or to the words that are in the second or further position in multiple entries (e.g., BRABEC refers to the multiple entry VRABEC / BRABEC). Finally, summary entries represent summaries of word roots or stems of some groups of basic entries; they contain brief etymological, dialectal, onomastic and geographic explanations. ${ }^{3}$

At this point, it is necessary to mention the fact that the processing of the Dictionary of Moravian and Silesian Anoikonyms is a genuinely interdisciplinary work. As a dictionary, it should follow the rules of lexicographic principles (e.g. Čermák and Blatná 1995); as a work processing proper nouns, it should follow the rules of onomastic theory (e.g. Šrámek 1999, Harvalík 2004); and since most of the material has been recorded as part of its dialect background, in dialect forms, the authors of the Dictionary must be experienced in dialectology, as they are, because they are authors of the Czech Linguistic Atlas (CLA; 1992-). Moravia and Silesia are regions considerably diversified in dialects, and not very rarely a situation occurs that in order to "decipher" a certain anoikonym, to identify the proper grammatical case of a noun in the prepositional anoikonym or to construct the corresponding headword, it is necessary to consult the CLA or other dialectological resources, especially the Archive of Folk Speech ${ }^{4}$, and regional dialectal dictionaries. Otherwise we would hardly be able to identify e. g. the meaning and grammatical structure of the anoikonym $U$ Četyňory,

${ }^{3}$ The introduction of summary entries was one of the reasons why the Brno workgroup could not start gradual publishing of the Dictionary and keep up that way with the Prague group. The summary entries present i.a. a list of all basic entries, which cross-refer to any given summary entry. For example, in the entry -bran-/-brán-, there probably will be cross-references to the basic entries BRÁNA, NADBRANČÍ, NADBRANÍ, OBRANA, PODBRANČÍ, PŘEDBRANÍ, ZÁBRAŇ, ZÁBRANA, ZABRÁNA, ZÁBRANČÍ, ZÁBRANEK, ZÁBRANÍ, ZÁBRANICE, ZÁBRANKA. Many of these entries have prefix headwords; these occur mostly from the end of the alphabet, therefore they have not been dealt with yet. In the preliminary concept of a given summary entry, headwords are only being taken from the Inventory of Headwords of the Dictionary of Moravian and Silesian Anoikonyms (Šrámek and Pleskalová, 1993). This Inventory was compiled nearly 20 years ago in view of the then planned concept of the dictionary. For our workgroup, which is creating the Dictionary according to quite a different conception, it can serve only as auxiliary, additive material that needs to be complemented continuously. On that account, the final form of the summary entry mentioned can be made as late as the final digitizing of all filing cards of the basic entries, to which this summary entry will then cross-refer. (The Prague group works with an inventory of headwords as well; it is called Index of Lexical Units of the Anoikonyms in Bohemia (Olivová-Nezbedová and Matúšová 1991) and it was published internally by the Institute of the Czech Language in 1991. The Index was compiled shortly before the start of work on the Dictionary of Minor Place Names in Bohemia which therefore corresponds with the then accepted conception of that work.)

${ }^{4}$ Archive of Folk Speech, inventory of approx. one million paper filing cards registering dialect expressions, deposited in Brno. 
recorded in East Silesia. We find in the literature that četyna means 'fir-needles', četyňor is a 'man living in a forest' or, in transferred meaning, a 'man of coarse manners'. In this anoikonym indicating a local area, it is a nickname of local inhabitants, the anoikonym itself is composed of a presposition $u$ expressing position and the dialectal form of gen. pl. of the name Četyňoř; in literal translation it means 'at the place where people of coarse manners live' (the heardword is ČETYŇÁ $\breve{R}$ - a construct dismissing the dialectal vowel change á $>o$ ). Another example: the anoikonym Adamove, denominating a field and recorded in Silesia, is identified as a local dialectal form of a substantivized possessive adjective, neuter sg., which is in fact a dialectal composed adjectival form with shortened -é. The literal meaning is 'a thing belonging to Adam', in literary Czech Adamovo. Nevertheless, when recorded in Central Moravia, this anoikonym is identified as a dialect form (with the change $y>e$ ) of Adamovy, which is a pl. noun derived from the personal name Adam by the suffix -ovy, that has only a historic connection with the above mentioned possessive adjective. The headword in the first case is ADAM, in the second case ADAMOVY. Sometimes a problem occurs when two different developmental lines result in the same form. E. g. the anoikonym $\mathrm{Na}$ Dobšech, when recorded in South Moravia, can reflect either the local morphological form of the loc. pl. of the personal name Dobeš, than it would mean 'at the place belonging to the Dobeš family', or the loc. form of the nom. Dobše, which is a regularly formed nonpersonal pl. anoikonym (parallel e. g. with the pair Adamik - Adamiky). In all other places, it could be only the second case. In the first case, the headword is DOBEŠ, in the second case DOBŠE.

So far, we have only digitized filing cards filed under the letters $A-H$; however, since one digital card is made for each word of the anoikonym recorded on one filing card, the whole corpus of anoikonyms is digitized simultaneously. Thus, the anoikonym U vérové bódy 'near the owl's shack' will be recorded on three digital cards: for the entries U, VÝR and BOUDA.

The digitization begins with the transfer of the paper filing card onto the digital card(s). (See Fig. 1.)

Into the uppermost box, the headword in capitals is written, for example the entry BOUDA 'shack'. The respective anoikonym is recorded in triple format: the top line represents the so-called standardized form - the form grammatically and phonologically corresponding to the literary language, the middle line represents the form reflecting the dialect grammatical form, and the bottom line shows a slightly simplified authentic record, reflecting also dialect phonology. Example: U výrovy boudy / U výrovej boudy / U vérové bóde.

Then there are several boxes to fill in that serve among others as a program function which is able to automatically arrange the anoikonyms in the first, $i$. e. material paragraph of the entry according to some predefined criteria. First is the box for the so-called "code" expressing the basic syntactic structure of the anoikonym by means of a combination of two or three letters. With slight 
modification, this categorization was adopted from the Prague onomastic group. ${ }^{5}$ In the box just under the headword, there is an indication whether

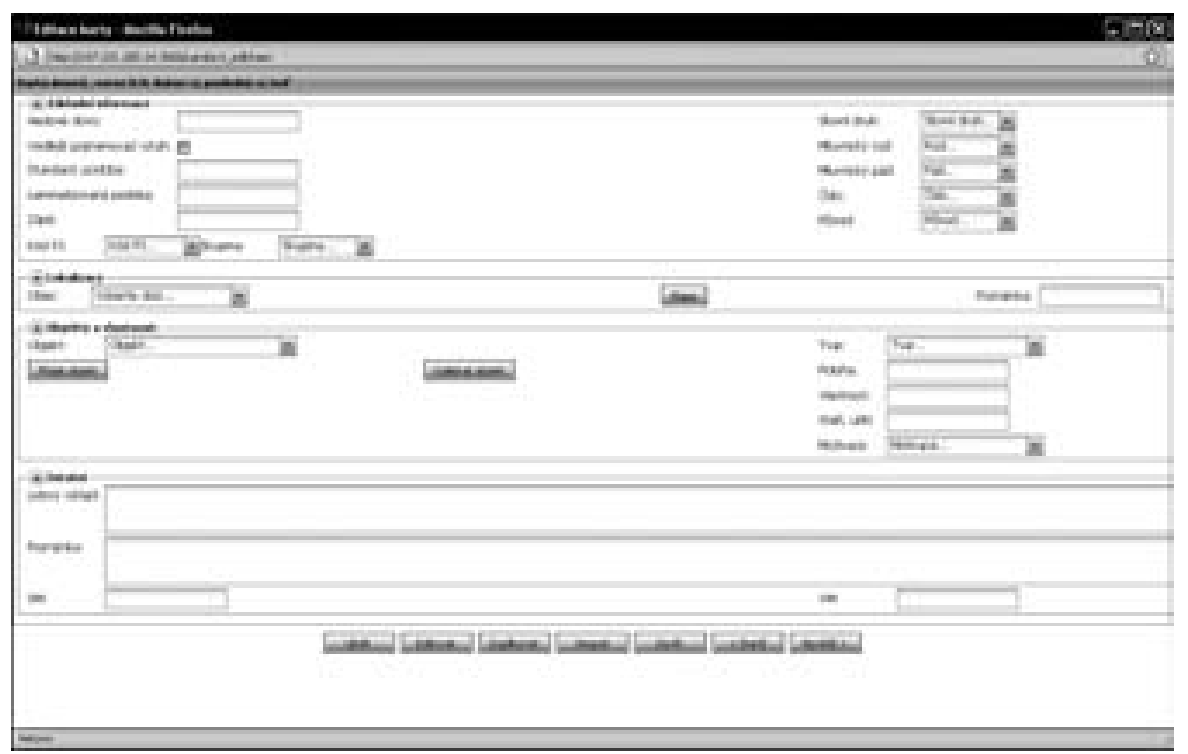

Figure 1: Digital card (empty):

the word corresponding with the headword is the part of a superordinate or subordinate denominating relation. ${ }^{6}$ Then there is a box with the so-called "group". The respective word is qualified according to in what forms the word expresses possessiveness. ${ }^{7}$ And finally, there is a box recording the so-called

${ }^{5}$ The first letter of the code can be a or $\mathbf{b}$ : a means a non-prepositional name and $\mathbf{b}$ a prepositional one. The other letter can be $\mathbf{a}, \mathbf{b}, \mathbf{c}, \mathbf{d}$, or $\mathbf{e}$ according to whether the name identified is a one-word name or a two-word name with a concordant attribute, a multi-word name without the conjunction $a$ 'and', another multi-word name with the conjunction $a$ or a two-word name with a non-concordant attribute. A plural anoikonym is marked with the letter $\mathbf{p}$, which is attached as the third sign of the code. So, for example, the code of the anoikonym Bouchálek is aa; $V$ Bouñovci ('in Bouňovec') ba; Výrova bouda ('an owl's shack') ab; U výrovy boudy ('near the owl's shack') bb; and Hory nad boudami ('mountains above the shacks') acp.

${ }^{6}$ In a subordinate relation a word or prepositional phrase stands in the function of nonconcordant attribute of a name which represents the superordinate relation, e.g., in the anoikonym $U$ výrovy boudy, the word bouda on the digital card with the headword BOUDA stands in a superordinate denominating relation, but in the anoikonym Hory nad boudami, the word bouda stands in the subordinate relation.

${ }^{7}$ The words are qualified by the Roman numerals I, II or III. Most words belong to the group I, which is negative in expressing possessiveness. Groups II and III relate only to persons, and on exception also to animals. Also, the names of persons in anoikonyms can be negative in expressing possessiveness, e.g., Novák - a surname functioning as 
motivation in the right-hand section of the digital card, which creates a sequence of anoikonyms of the same structure and similar or logically linked motivation of the adjective in nominal entries, as well as of the nouns in adjectival entries. ${ }^{8}$

A digital card contains yet more information. The upper right section records word class, grammatical categories and the origin (from an appellative, from a proper name: personal name, place name, minor place name or other name) of that part of the anoikonym which corresponds with the headword. This data will not be reflected in the entry of the traditional version of the Dictionary. Nevertheless they will enable a search for respective categories in the digital Dictionary, as well as for further data characterizing the object. Further boxes on the card are used to record the locality, the type of the named object and a possible folk explanation of the name. Down on the right hand side of the card, one finds a box for the so-called "relation model"9 (See Fig. 2).

anoikonym (a name of a field after its owner). Group II contains words which express possessiveness with the genitive form of nominal or adjectival personal names, e.g., Nováka Josefa louka ('the Josef Novák's meadow'), Za Nováků lesem ('behind the Novák's meadow'), Nad Novotného polem ('above the Novotný's field'). Group III comprises the names which express possessiveness by a possessive adjective, e.g., $Z a$ Novákovou jámou ('behind the Novák's pit').

${ }^{8}$ Thus, a list of combinations of the three first letters of the alphabet and sequence numbers has been created. The list of motivations is based on the paper Třidèni pomistnich jmen [Classification of Anoikonyms] by Vladimír Šmilauer (Šmilauer 1960, 1972). His classification was slightly modified to comply with the needs of our Dictionary. The motivation of concordant attributes is marked with $\mathbf{A}$ or $\mathbf{B}$ as the first sign: $\mathbf{A}$ denotes absence of possessiveness and $\mathbf{B}$ its presence. The $\mathbf{A}$ motivation is further divided into "general qualities and relations": A1-A25; "processes, actions and results of processes": A26; "Earth": A27-A57; e.g. the "location" has the indication A3 and all anoikonyms with this motivation are sequenced in the material paragraph of the entry in alphabetical order: Dolni/Horni ${ }_{2} /$ Spodni b-da ('lower/upper/bottom shack'); or the "colour" has motivation A19 and respective attributes are again sequenced: Černá/Stř́ibrná/Zelená $b$-da ('black/silver/green shack'). The B motivation is further divided into B1: "plus person: appellatives" (U cikánové/kovárové/pastýrové b-dy 'near the gypsy's/smith'/herd's shack'); B2: "plus person: proper names" (U Cyrilové/Čipkové/Divišové/Dvořáčkové/ Fičákové b- $d y$ 'near Cyril's/Čipek's/Diviš'/ Dvořáček's/Fičák's shack'); B3: “minus person: appellatives" (U kocourové /medvědi/psí/vlči/výrové ${ }_{5} b$-dy 'near the tom-cat's/ bear's/dog's/wolf's/owl's shack'), B4: "minus person: proper names" (Alikova bouda 'Alík's shack'; Alík is a dog). - Noun motivations in the anoikonyms with respective codes are marked $\mathbf{C}+$ sequence number 1-71, again after Šmilauer. So in adjectival entries, the nouns in the material paragraph are again logically sequenced because of the symbol of motivation. Thus, when the motivation "water" has the symbol $\mathbf{C 3 5}$, all substantives with this motivation in the entry BÍLÝ 'white' are automatically sequenced in alphabetical order: U bilé studánky/studně/vody ('near the white spring/well/water'); or the motivation "profane buildings and their parts" has the symbol $\mathbf{C 6 3}$ and the corresponding part of the material listing looks like this: Bílé domky/mostky/sloupky ('white little houses/small bridges/columns').

${ }^{9}$ The category "relation model" was used by Jana Pleskalová in her monography Tvořeni pomistnich jmen na Moravě a ve Slezsku [Formation of Anoikonyms in Moravia and 
The process of conveying the information from the filing cards into the database requires a great deal of time. However, there is a great benefit in doing it: The first and second paragraphs of the entry are created automatically. In entries of up to five anoikonyms, the first paragraph shows the respective anoikonyms in the shape listed in the box "record" on the digital card, i. e., in their real form, together with types of objects and locality. In entries containing more then five anoikonyms, the forms notregistering the phonological variants, i.e., forms listed in the second box, are sequenced, so that their joint frequency can be presented. This is marked by subscripts after the names.

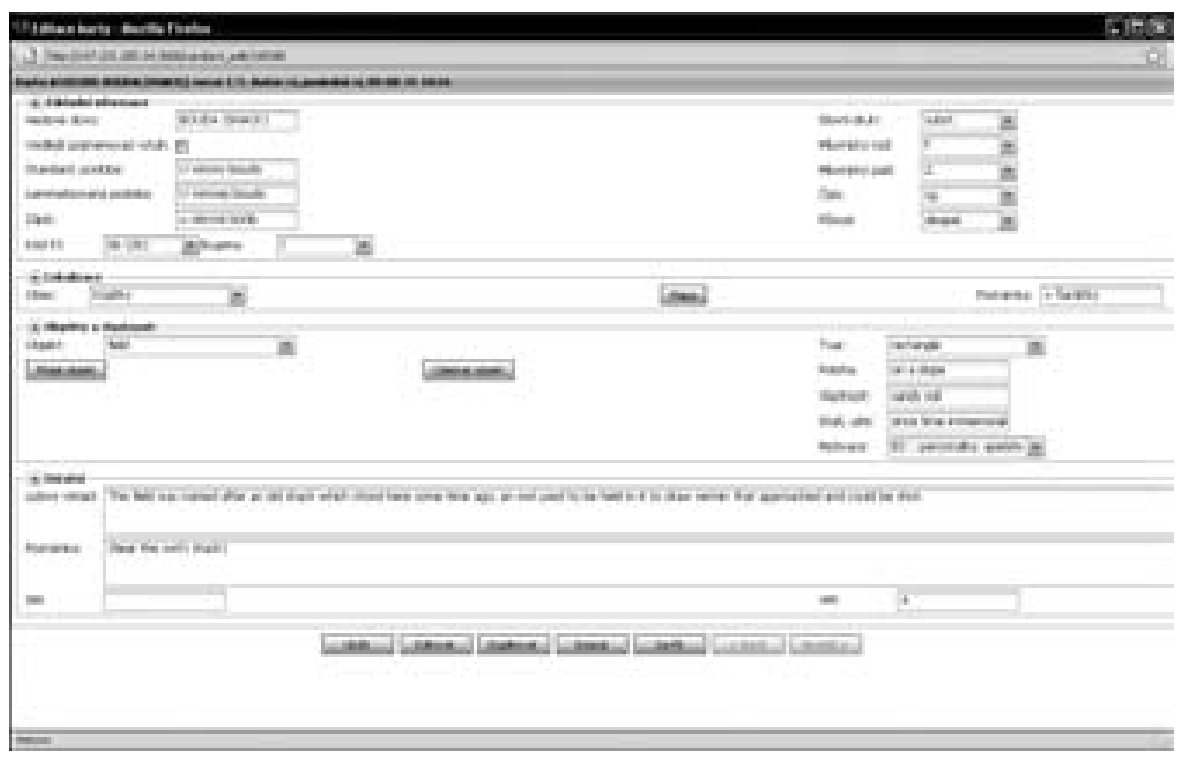

Figure 2: Digital card (filled in):

When all anoikonyms belonging to a certain entry are stored in the database, it is time to formulate the third, explanatory paragraph. This is the main part of the work on the entry, as the first two paragraphs are processed automatically. In this paragraph, the word-formative, syntactic, onomastic, dialectal and geographic characteristics of respective anoikonyms are summarized and possibly references to summary entries and to the literature are mentioned. This occurs regularly with the Index of Lexical Units of the Anoikonyms in Bohemia, Místní jména na Moravě a ve Slezsku [Moravian and Silesian Place Names] by Ladislav Hosák and Rudolf Šrámek (Hosák and Šrámek 1970, 1980), Mistní jména v Čechách [Bohemian Place Names] by Antonín Profous and Jan

Silesia] (Pleskalová 1992; her categorization is based on the conclusions by Rudolf Šrámek, see Šrámek, 1972): A "position", B "directly expressed type of the object", C "qualities", and D "possessiveness and relation to a person". According to this classification, the anoikonym Bouda is B and U Boudy ('near the shack') is A. 
Svoboda (Profous, Svoboda 1947-1960), where necessary Českýjazykový atlas [Czech Linguistic Atlas] (CLA 1992-), Vlastivěda moravská [Moravian Homeland Study] (1897- ), etymological dictionaries by Václav Machek (Machek 1968), Josef Holub and František Kopečný (Holub and Kopečný 1952), Jiří Rejzek (Rejzek 2001) or Stefan Michael Newerkla (Newerkla 2004) and also with references to summary entries. Here in the explanatory part it is possible to provide a dialect comparison of the appellative and anoikonymic material.

Individual types of entries, in their preliminary form, look as follows for example:

Basic entry (up to five anoikonyms):

BOUDNISKO $_{3}$, n.

1+2 I a Búdnisko field Medlovice UH; Bódniska field Roštín KM (Divoky), Bódniska field Zdounky KM (Těšánky)

3 The anoikonym $B$. is derived from the noun bouda with the suffix -nisko or from the adj. boudný with the suffix -isko (possibly it could arise from a multi-word phrase *boudné pole, *misto s boudami - 'field, place with shacks'). In Medlovice UH "narrow strips of fields where some shacks used to be", in Divoky and Těšánky (both KM) n. pl. - "once pastures where shacks used to be for herds to spend the night in" (the ground lies between both villages). See BOUDA, adj. boudný see also BOUDNÝ, BOUDŇÁK. Anoikonyms were recorded in a small area west from Zlín.

See -boud-/-bud-

\section{Basic entry (more than five anoikonyms):}

BOUDA $_{184} \mathrm{f}$.

1 I a $B$-d $a_{3} ; B$-dy $y_{11} ; V r c h n i_{2} b$-da, Černá/Stř́brná/Zelená $b$-da, Nová/Stará ${ }_{2} b$-da, Kamenná /Sennáa/Zděná b-da, Raškovská/Rohelská b-da, Pytlácká b-da, Cyrilova/ Fuchsova/Gřipkova/Hanzlova/Hraběnčina/Janečkova/Muchova/Strakova /Valou-

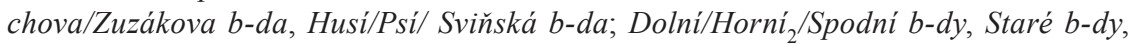
Panské b-dy; B-da v luku b Na b-dě ${ }_{5}$, Pod b-dou,$U$ - b-dy ${ }_{32}, \mathrm{Za} b$-dou $;$; Na b-dách, $N a$ B-dech, Pod b-dama ${ }_{2}$, Pod b-dy, V b-dech; K lišči b-dé, Ku financové b-dě, Pod kamennou b-dou, Pod Bučkovou/Matoušovou b-dou, U Dvoŕáčkovy b-dy, $U$ dolni ${ }_{3} b$ $d y, U$ bilélčerné/zelené $b-d y, U$ staré ${ }_{5} b-d y$; U Starých $b$ - $d$; U shořelej/spálené/spálenej

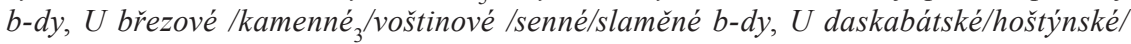
jedelské/rohelské $e_{3} b-d y$, U Cikánkové/kovárové /panáčkové/pastýrové/pytlácké/ruskél žebrácké b-dy, U Cyrilové/Čipkové/Divišové/Dvořáčkové/Fičákové/Halikové/ Hubalovej/Chramostov/Jónové/Kopečkové/Plachové/Prokšové/Sajtlové/Skřivánkové/Slavikové/ Škrobánkovej/Švestkové/Tylové/Vašíkové/Žalmanové b-dy, U kocourové/medvědi/psí/vlči /výrové ${ }_{5} b$-dy, U hradiskej b-dy, Ve staré b-dě, Za horni ${ }_{2} b$-dou; $U$ b-dy v Uhliskách - a Díl pod b-dama ${ }_{2}$, Louka u b-dy, Lubná u b-dy; Čtvrtě od b-dy, Hory nad b-dama, Kukle pod b-dou b Nad slatinou u b-dy, Za lesem $k$ b-dě

2 a forest ${ }_{9}$, field ${ }_{6}$, shack , building $_{4}$, cabin $_{4}, \mathrm{inn}_{4}$, wine-vault ${ }_{3}$, bridge, clearing, garden, log cabin, mines, place, spot height (a marked point usually on top of a hill), vineyard

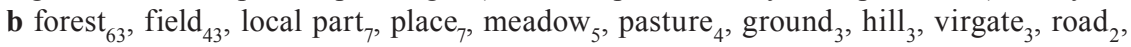
alley, allotment, clearings, place in the forest, valley, vineyard $\bullet$ field $_{4}$, hills, meadow, vineyard $\mathbf{b}$ field, ground

3 Included anoikonyms are related to the noun bouda; as an anoikonym, it usually indicates smaller, not permanently inhabited, solitary buildings (the names occur regularly 
in the sg. form), generally serving as orientation point in the landscape or forest. It binds with attributes, derived most often from the owner or inhabitant(s) (Cyrilova / Fuchsova bouda 'Cyril's / Fuchsa's shack', Hraběnčina bouda 'the Countess' shack', U ruské boudy 'near the Russian shack' - "a shack used to be here in which Russian prisoners of war dwelled who worked in the forest"); after the village or town in the direction or in the area of which they are situated (U dalskabátské / holštýnské boudy 'near the Dalskabáty / Holštýn shack'); after the colour (U bilé boudy 'near the white shack', Stríibrná bouda 'silver shack'); after a location - Horní / Dolni bouda 'upper / lower shack'); in reference to age (Nová / Stará bouda 'new / old shack'); after the building material used (Kamenná bouda 'stone shack', U slaméné boudy 'near the straw shack') or after the material kept in it (Senná bouda 'hay shack'); after animals (U psí / vlči boudy 'near the dog's / wolf's shack') or birds (Husí / Výrova bouda 'goose / owl's shack'); after a local event (U spálené boudy 'near the burned shack'). The names of adjacent allotments often survive even if the object perished (it is often the case with local parts).

The word bouda can rarely be found as the name of an inn (Muchova bouda 'Mucha's shack' near Brno, Psi bouda 'dog's shack' in Frenštát NJ, Vrchni bouda 'upper shack' in Tovéř OL).

Sometimes, the lexeme boudy pl. has a specific meaning: around Hodonín, it denotes contemporary or former wine cellars: Búdy 'shacks' in Josefov, Mutěnice, Milotice, $\mathrm{Na}$ búdách 'on the shacks' in Louka; in these names, the lexeme bouda actually means the brick room in front of the proper wine cellar, which then gave the name to the entire place; Panské boudy 'manor shacks' is the name for mines named after wooden entrance covers which sheltered each mine against bad weather; mines belonged to local aristocracy. In the genitive pl. of the noun bouda, no shortening of the stem vowel occurs ( $U$ boud, U starých boud, see CLA 4, 221).

Anoikonyms related to the word bouda were recorded above all in the southern half of Moravia, with the greatest concentration around Brno, Kyjov and further in the surroundings of Zábřeh and Litovel; a lesser density of these names appears in Silesia, in Walachia and in the northern part of the Bohemian-Moravian Highlands (these anoikonyms are not typical for higher lying areas). - IPJČ; HŠ 1, 101 Bouda Člunovská. Viz -boud-/-bud-

\section{Cross-reference entry:}

\section{BUDKA see BOUDKA // BUDKA}

\section{Multiple entry:}

BOUDKA ${ }_{13} / /$ BUDKA $_{9} \mathrm{f}$.

1 I a Boudky ${ }_{2}$, Budky; Výrova boudka b Pod boudkou, Při budce, U boudky ${ }_{3}, U$ budky ${ }_{2}$, $V$ boudce; U Boudek, $V$ boudkách; $U$ dolni budky, U kamenné boudky, U kamenné budky, U Výrové boudky a Smušky při budce

2 a cabin, farm, field, forest $\mathbf{b}$ forest ${ }_{8}$, field ${ }_{3}$, place $_{3}$, allotment, pastures, stone quarry $\rightarrow$ a field

3 Included anoikonyms are related to the diminutive form of bouda. It occurs in anoikonyms denoting creaky or ramshackle shacks or allotments in their neighbourhood. The anoikonym Boudky 'small shacks' / U boudek 'near the small shacks' in Velké Němčice BV refers to a farmstead. The anoikonym Výrova boudka 'an owl's shack'/ U Výrovy boudky 'near the owl's shack' (Blažovice BO) names "a shack in which hunters held an owl as a lure". See also BOUDA. In the form bouda, the change of quantity in the stem does not occur, contrary to the dim. budka - see CLA 5, maps 161-165. The shortened form that occurs with diminution undoubtedly occurs only in two anoikonyms in South Moravia (U kamenné budky 'near the small stone shack' Buchlovice UH, Smušky při 
budce, Kuželov HO); in other anoikonyms containing the word budka in Silesia it is not certain whether the creation of a shortened form did not occur recently during the dropping of the quantitative opposition in Silesian dialects.

The names containing the form boudka were recorded approximately in a north-to-south strip of land in the middle of Moravia, with the greatest concentration west of Brno; budka occurs farther to the east: rarely in the Slovak region, more often in Silesian dialects. - IPJČ́; HŠ 1, 101 Boudky. Viz -boud-/-bud-

\section{Summary entry:}

- boud-/-bud-

- To this stem belong the lexemes bouda 'shack'and budova 'building' (and derivatives), though it is not certain how far and if ever they are etymologically related. According to Machek, both words are of Slavic origin (from budovati 'build'); however, there are other opinions: the word bouda can be (Holub-Kopečný), probably is (Rejzek) or definitely is (Newerkla) taken from German (Middle High German buode 'a cabin, a great tent').

- Dialect forms: -boud-, bód-, -búd-, -bud-

- Frequently occurring in the whole area.

- BOUDA, BOUDECKO, BOUDECKÝ, BOUDKA/BUDKA, BOUDŇÁK, BOUDNĚ, BOUDNICE, BOUDNISKO, BOUDNÝ, BOUDOVÝ, BUDEL, BUDKA, BUDKOVCOVÝ, BUDKOVEC, BUDNÍ, BUDOŠ, BUDOVA, BUDOVAŇA, BUDOVNÍK, BUDUNEK /BUDYNEK

Important components of the entries are maps. Their image and the possibilities of working with them are presently being intensively refined. In the traditional version of the Dictionary, some entries will be supplemented by schematic maps. For such maps, it will be possible to choose from various kinds of map backgrounds (district borders, without district capitals or with them, network of roads, network of waterways, vertical model, etc.), into which symbols are projected on places where respective anoikonyms were recorded. In the future, it will be possible to combine more entries in one map as is already possible with multiple entries, e. g., BOUDKA // BUDKA (see Fig. 3).

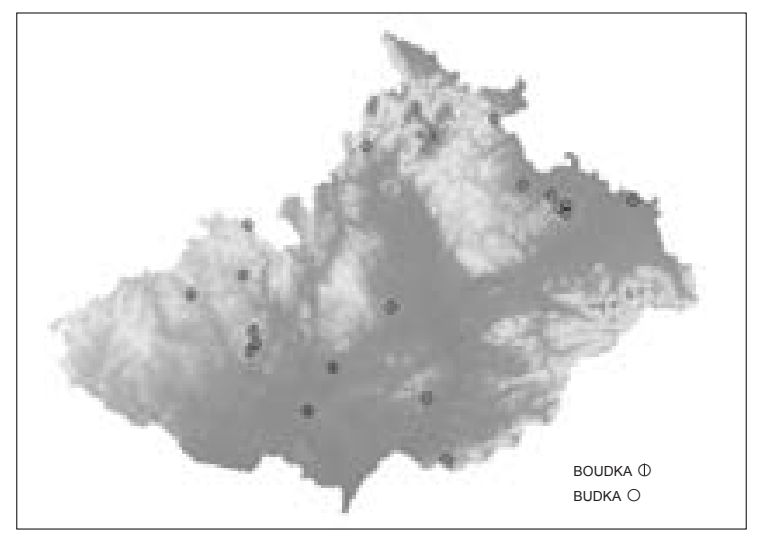

Figure 3: Schematic map - vertical model of the multiple entry BOUDKA // BUDKA 
Thus, one can compare the territorial distribution and frequency of occurrence of more sets of anoikonyms.

Naturally, the users of the digital version of the Dictionary will be able to work with the maps, to study maps for entries according to their own selection, to choose any map features; a click on a symbol will show all data for the respective anoikonym that had been put on the digital card and it will be possible to search these data according to set criteria. The on-line version will enable projecting the anoikonymic material into Google maps with all the possibilities that Google offers, i.e., with any approximation, with satellite or air photo. During such an operation, any symbol will show the data from the digital card (See Fig. 4).

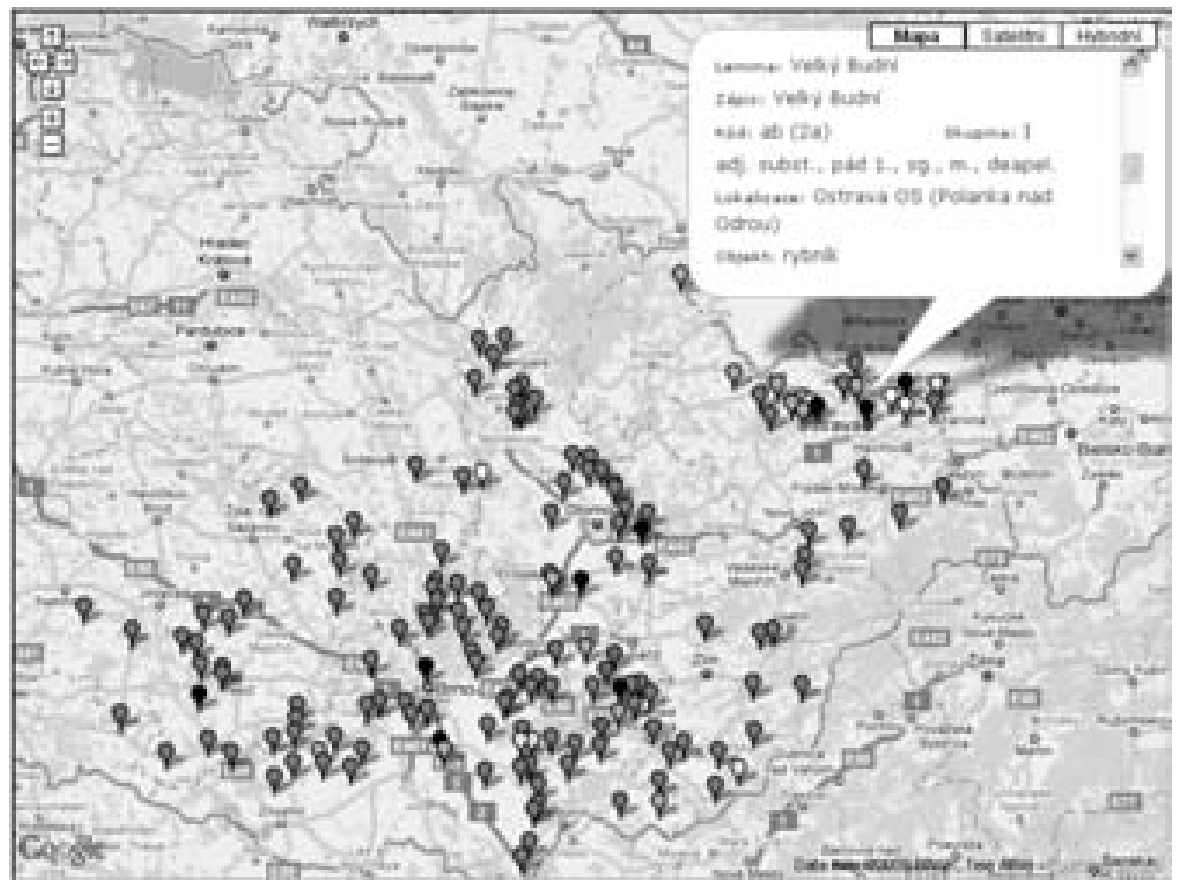

Figure 4: Google map - summary entry -boud-/-bud-:

And last but not least, these maps - the digital ones as well as those in the paper version - enable comparison with existing dialectological maps depicting geographical distribution of appellatives and presented in the Czech Linguistic Atlas.

Let's hope that this work will turn into an important enterprise, not only within Czech onomastics. ${ }^{10}$

10 This paper has been compiled on the basis of a grant by the Czech Science Foundation, No. 405/08/0703 Slovník pomístních jmen na Moravě a ve Slezsku II (teoretické a interpretační aspekty). 


\section{REFERENCES}

František ČERMÁK and Renata BLATNÁ (eds.), 1995: Manuál lexikografie [Manual of Lexicography]. Jinočany: $\mathrm{H}$ and $\mathrm{H}$.

Český jazykový atlas [Czech Linguistic Atlas]. 1992-: $1^{\text {st }}$ volume 1992. $2^{\text {nd }}$ volume 1997. $3^{\text {rd }}$ volume 1999. $4^{\text {th }}$ volume 2002. $5^{\text {th }}$ volume 2005. $6^{\text {th }}$ volume (Supplements) at the printers. Praha: Academia.

Milan HARVALÍK, 2004: Synchronní a diachronni aspekty české onymie [Synchronic and diachronic aspects of Czech onomastics]. Praha: Academia.

Josef HOLUB and František KOPEČNÝ, 1952: Etymologickýslovnik jazyka českého [Etymological Dictionary of the Czech Language]. Praha: Státní nakladatelství učebnic v Praze.

Ladislav HOSÁK and Rudolf ŠRÁMEK, 1970: Místní jména na Moravě a ve Slezsku [Moravian and Silesian Place Names]. A-L. Praha: Academia.

Ladislav HOSÁK and Rudolf ŠRÁMEK, 1980: Mistní jména na Moravě a ve Slezsku [Moravian and Silesian Place Names] M-Ž. Praha: Academia.

Václav MACHEK, 1968: Etymologický slovnik jazyka českého (druhé, opravené a doplněné vydání) [Etymological Dictionary of the Czech Language - second edition, corrected and amended]. Praha: Academia.

Jana MATÚŠOVÁ (ed.), 2005: Slovník pomistnich jmen v Čechách [Dictionary of Minor Place Names in Bohemia] I (A). Praha: Academia.

- - (ed.), 2006: Slovník pomístních jmen v Čechách [Dictionary of Minor Place Names in Bohemia] II (B-Bau). Praha: Academia.

- - (ed.), 2007: Slovnik pomístnich jmen v Čechách [Dictionary of Minor Place Names in Bohemia] III (Bav-Bid). Praha: Academia.

- - (ed.), 2008: Slovník pomístních jmen v Čechách [Dictionary of Minor Place Names in Bohemia] IV (Bíg-Bož). Praha: Academia.

- - (ed.), 2009: Slovník pomistnich jmen v Čechách [Dictionary of Minor Place Names in Bohemia] V (Bra-Buc). Praha: Academia.

Stefan Michael NEWERKLA, 2004: Sprachkontakte Deutsch - Tschechisch Slowakisch. (Language Contacts German - Czech - Slovak). Frankfurt am Main: Peter Lang.

Libuše OLIVOVÁ-NEZBEDOVÁ and Jitka MALENÍNSKÁ, 2000: Slovník pomistních jmen v Čechách - úvodní svazek [Dictionary of Minor Place Names in Bohemia - Introductory volume]. Praha: Academia.

Libuše OLIVOVÁ-NEZBEDOVÁ and Jana MATÚŠOVÁ, 1991: Index lexikálních jednotek pomístnich jmen $v$ Čechách [Index of Lexical Units of the Anoikonyms in Bohemia]. Praha: Ústav pro jazyk český ČSAV.

Jana PLESKALOVÁ, 1992: Tvořeni pomistnich jmen na Moravě a ve Slezsku [Formation of Anoikonyms in Moravia and Silesia]. Jinočany: $\mathrm{H}$ and $\mathrm{H}$.

Antonín PROFOUS and Jan SVOBODA, 1947-1960: Mistní jména v Čechách [Place Names in Bohemia] I-V. Praha: Nakladatelství Československé akademie věd. 
Jiří REJZEK, 2001: Český etymologický slovník [Czech Etymological Dictionary]. Voznice: LEDA.

Vladimír ŠMILAUER, 1960, 1972: Třídění pomístních jmen [Assorting of Anoikonyms]. In. Zpravodaj Mistopisné komise [Bulletin of the Topographical Board] 1, 1960, 149-180; reprint: Zpravodaj Místopisné komise [Bulletin of the Topographical Board] 13, 1972, 171-204.

Rudolf ŠRÁMEK, 1972: Toponymické modely a toponymický systém [Toponymic Models and Toponymic System]. In: Slovo a Slovesnost 33, 1972, 304-318.

Rudolf ŠRÁMEK, 1999: Úvod do obecné onomastiky [Introduction to General Onomastics]. Brno: Masarykova univerzita.

Rudolf ŠRÁMEK and Jana PLESKALOVÁ, 1993: Heslář ke Slovníku pomístnich jmen na Moravě a ve Slezsku [Inventory of Headwords of the Dictionary of Moravian and Silesian Anoikonyms]. Brno: ÚJČ AV ČR (unpublished).

Vlastivěda moravská [Moravian Homeland Study]. 1897-. Old Library 1897-2002, 1-68. New Library 1992-.

\section{OBDELAVA METODOLOŠKIH IN DIALEKTOLOŠKIH POGLEDOV NA SLOVAR MORAVSKIH IN ŠLEZIJSKIH ANOJKONIMOV (IMENA MANJŠIH KRAJEV)}

Članek predstavlja postopek, ki so ga uporabili jezikoslovci iz Brna pri pripravi Slovarja moravskih in šlezijskih anojkonimov (Dictionary of Moravian and Silesian Anoikonyms); slovar je zasnovan kot abecedni inventar posamičnih anojkonimov in skupnih gesel. Rezultati bodo predstavljeni $\mathrm{v}$ tradicionalnem slovarju v knjižni obliki in v multifunkcionalni interaktivni digitalni različici, ki bo ponujala veliko možnosti za iskanje želene informacije in prikaz na kartah. Zbrano gradivo je bilo postopoma vstavljeno $\mathrm{v}$ digitalno bazo podatkov programa, ki avtomatično ustvarja primarno obliko gesla. Glavna naloga avtorjev je, da oblikujejo razlagalni del vsakega gesla, povezanega z vprašanji besedotvorja, skladnje, dialektologije, etimologije, onomastike in geografije, ki se nanašajo na vključena imena.

Izdelava slovarja je interdisciplinarno delo - kot slovar sledi leksikografskim načelom; kot delo, ki obdeluje lastnoimenske samostalnike, sledi pravilom onomastične teorije. Avtorji slovarja so izkušeni dialektologi.

Dobro ohranjena narečja $v$ regiji povzročajo nekatere težave, npr. kako reflektirati realno obliko anojkonima v slovarju skupnih gesel. Poznavanje narečij pogosto pomaga pri »dešifriranju« danega imena in pri določanju njegove geneze ter motivacije. Računalniški program ponuja tudi možnost generiranja kart (na različnih ozadjih), ki dopuščajo primerjavo z obstoječimi dialektološkimi kartami, ki slikajo zemljepisno porazdelitev apelativov in so predstavljene v Češkem lingvističnem atlasu (Czech Linguistic Atlas). 